AUTHOR:

Farrelli Hambulo ${ }^{\top}$

Leonie Higgs²

AFFILIATION:

1 University of Zambia, School of

Education, Department of Religious Studies.

${ }^{2}$ College of Education, Department Education Foundations, University of South Africa

CORRESPONDENCE TO:

Farrelli Hambulo

EMAIL:

farrelli.hambulo@unza.zm

POSTAL ADDRESS:

P.O. Box 32379, Lusaka, Zambia.

CORRESPONDENCE TO:

Leonie Higgs

EMAIL:

higgslg@unisa.ac.za

POSTAL ADDRESS:

Department Educational Foundations,

College of Education, UNISA, PO Box 392, 0003

DATES:

Published: 5 Mei. 2017

HOW TO CITE THIS ARTICLE: Hambulo, F. \& Higgs, L., 2017. Catholic secondary education and identity reformation in Zambia's Southern Province: an outcome of a conflict of educational policy values or not? KOERS - Bulletin for Christian Scholarship, 82(1). Available at: https:// doi.org/10.19108/KOERS.82.1.2279

COPYRIGHT:

(c) 2017. The Author(s).

Published under the Creative

Commons Attribution License.

\section{Catholic secondary education and identity reformation in Zambia's Southern Province: an outcome of a conflict of educational policy values or not?}

\section{Opsomming}

Hierdie artikel, "Katolieke sekondêre onderwys en identiteitsreformasie in Zambië se Suidelike Provinsie: 'n Gevolg van strydige waardes van onderwysbeleid of nie?", is 'n uitvloeisel van 'n studie getitel "Katolieke sekondêre onderwys en identiteitsreformasie in Zambië se Suidelike Provinsie". Die artikel dui aan dat sedert Katolieke skole in Zambië gevestig is, hulle deel van daardie land se onderwysvoorsiening uitmaak en oor die jare 'n goeie reputasie as verskaffers van onderwys van 'n goeie gehalte opgebou het. Sedert Zambië se onafhanklikwording in 1964 het Katolieke onderwys egter'n ongewenste identiteitsverandering of -reformasie ondergaan, wat behels dat dit van Katolieke onderwyspraktyk, soos a anbeveel in Katolieke onderwysbeleid, afwyk. Kenners van Katolieke onderwys in Zambië en die Zambiese nasie erken die identiteitsverlies wat Katolieke skole sedert onafhanklikwording ondervind en gee hul ontevredenheid daarmee te kenne. Die betrokke kenners verwys slegs oorsigtelik na die probleem van identiteitsverlies wat Katolieke skole ondervind, wat tot gebrekkige insig in die probleem bydra. Die Zambiese nasie verwys slegs op spekulatiewe en onduidelike wyse na hierdie probleem, wat ook tot gebrekkige insig in die probleem van identiteitsverlies in Katolieke skole in die land bydra. Met verwysing na die argumente wat kenners van Katolieke onderwys oor hierdie probleem in Zambië aanvoer, is hierdie artikel gemoeid met die argumente wat Carmody (2007) aangaande die oorsake van ongewenste identiteitsreformasie in Katolieke skole aanvoer; die argumente word spesifiek met katolieke sekondêre skole in Zambië se Suidelike Provinsie in verband gebring met die doel om hulle te verifieer. Die artikel dui aan dat Carmody se argumente nie op Katolieke sekondêre skole in Zambië se Suidelike Provinsie van toepassing is nie en voer redes hiervoor aan. Die artikel gee ook'n tentatiewe beskrywing van die ongewenste identiteitsreformasie wat Katolieke sekondêre skole in die Suidelike Provinsie ondervind en sluit af met' $n$ uiteensetting van die vier ware oorsake van ongewenste identiteitsreformasie in Katolieke sekondêre skole in Zambië se Suidelike Provinsie.

Sleutelwoorde: identiteit, Katoliek, akademies. godsdienstig

\begin{abstract}
This article sets out to reflect critically on the causes of undesired identity reformation that has occurred in Catholic secondary schools in Zambia's Southern Province since the country gained independence from Britain in 1964. This critical reflection is necessitated by the fact that although scholars in the field of Catholic education and the Zambian people acknowledge the presence of undesired identity reformation in Catholic schools, this issue is presented in brief, speculative and indefinite terms. This is against a background where such schools have earned themselves a good reputation due to their provision of quality education to the Zambian people since independence. Catholics and other people concerned with the welfare of Catholic education have started to express their discontent with the identity reformation experienced by Catholic schools. This article, therefore, critically engages with Carmody's (2007) contentions regarding the causes of undesired identity reformation in Catholic schools and relates them specifically to Catholic secondary schools in Zambia's Southern Province in order to verify them. It is shown in this article that Carmody's contentions are not relevant in explaining the causes
\end{abstract}


of undesired identity reformation in Catholic secondary schools in Zambia's Southern Province.

As such, in stating the nature and the scope of the undesired identity reformation in Catholic

secondary schools in Zambia's Southern Province, the article highlights four genuine causes

of undesired identity reformation. These four genuine causes are linked to a weakening of

the "academic" and "religious" missions of Catholic schools, which contributes to their loss of

Catholic education identity as recommended in Catholic education policy.

Key words: Identity; Catholic; academic; religious.

\section{Introduction}

After Zambia had gained independence in 1964, the Catholic Church and the government formed an educational partnership meant to ensure the provision of quality education to the people. Therefore, from 1964 to date, Catholic schools have been functioning according to values that stem from evolving Catholic education policies and Zambian national education policies. Miller (2006:6) posits that the schools' success is based on their compliance with Catholic education policy.

However, Catholic schools have been experiencing undesired identity reformation in Zambia because of their deviation from global Catholic education policy. In light of the gradual, undesired identity reformation that has been experienced by Catholic schools since Zambia gained independence, Catholics and others interested in the welfare of Catholic schools have started to express their discontent with the current identity loss in these schools (Kabwe, 2010; Chisempere, 1993).

Scholars in the field of Catholic education in Zambia, for example, Carmody (2007), Kabwe (2010) and Chisempere (1993) are aware of the presence of the problem of undesired identity reformation in Zambian Catholic schools and also state its causes, but only in brief terms. Of particular concern to this study are scholarly sentiments advanced by Carmody (2007). According to Carmody (2007:550), there has been a conflict of values in the evolving Catholic education policies and Zambian national education policies since independence, which has led to undesirable identity reformation in Catholic schools because the schools function according to both sets of policies at the same time. Carmody (2007:550) further contends that in the educational partnership between the Catholic Church and the government that was formed shortly after independence, the government's policy directives regarding educational practice in the Zambian setting have always been regarded more highly than those of the Catholic Church, causing an imbalanced, one-sided partnership mostly in favour of government educational interests. The outcome of this has been the problem of undesired identity reformation in Catholic schools in Zambia since independence.

In line with the aforementioned, despite their awareness of the presence of the problem of identity loss in the schools, the few scholars in the field of Catholic education only state its causes in very brief terms. They do not categorically state and sufficiently elaborate on specific details concerning the schools' undesired identity reformation and, indeed, none of them attempt to provide a very detailed account of the nature and the scope of the identity reformation experienced by Catholic schools in Zambia. This aspect is also evident among the Zambian people, who speak about the schools' identity loss across the country in vague or speculative terms rather than definite terms (Kabwe, 2010:14).

In view of the aforementioned, the current study focuses on verifying Carmody's (2007) strong contentions, as referred to above, regarding the causes of undesired identity reformation in Catholic secondary schools in Zambia since independence. Further, the study focuses on providing a factual, definite and detailed account of the undesired identity reformation experienced specifically by Catholic secondary schools in Zambia's 
Southern Province since independence.

\section{Literature review}

Since the 1890s the Catholic Church has formed part of Zambia's educational provision. In the historical context of Zambian Catholic schools, the provision of Catholic education had passed through three major stages, namely, education under the British South Africa Company (BSAC), education under the British colonial government and education after independence when the Catholic Church strived to regain control of education from the newly formed Zambian state (Carmody, 2002:796).

In the first stage (1891-1924), education was under the control of the BSAC. During this period the Catholic missionaries were the main providers of education and used it for conversion purposes (Garvey, 1994; Parker, 1966; O'Brien, 2006). However, the BSAC was not fully committed to native education, as confirmed by its poor quality. The company was more concerned with amassing wealth from Zambia's mineral resources (Snelson, 1974), contributing to the serious neglect experienced by Catholic schools in Zambia (Weller, \& Linden, 1984:31).

In the second stage (1925-1964), education was administered by the British colonial government. Despite its obligation to educational provision, the colonial government was not genuinely committed to it, as was evidenced by a racially divided education system during this period. The education system later developed into a "dual education system" grounded in two separate education systems functioning at the same time, one for whites and the other for the native blacks. The colonial government prioritised the education of whites and neglected that of blacks as far as financial resources were concerned. Therefore, educational provision during this stage was characterised by quality education for whites and poor education for blacks in the same educational context. Despite the colonial government's scepticism regarding native educational empowerment during this stage, Catholic education upheld a non-discriminatory approach to educational provision, leading to a clash of educational interests between the Catholic Church and the colonial government. Within the context of the difference in educational interests between the two parties, the colonial government provided meagre financial support to Catholic education. This led to Catholic protests against the social injustices of the time, specifically the unfair dual education system and meagre educational grants for mission education in the protectorate (Kelly, 1999; O'Brien, 2006). Moreover, the colonial government was compelled to support native education, but only through meagre grants-in-aid in order to emphasise the provision of "adaptive education" to the natives (Berman, 1975). The natives highly resented the colonial government's emphasis on adaptive education. They regarded the provision of adaptive education as a non-progressive educational initiative that failed to enhance their aspiration to compete for the same white collar jobs held by their white counterparts in society. Furthermore, the natives resented adaptive education because they were convinced that it would not grant them the enlightenment deemed necessary for nationalisation (Kelly, 1999; O'Brien, 2006; Carmody, 2004). In a context of the provision of restricted education for the natives by the colonial government, the Catholic Church did not impose any restrictions on the type of education offered to the natives in its schools - it ranged from low levels to high levels and was mostly of moderate to high quality (Snelson, 1974; Carmody, 2004). The natives only needed to show a willingness to convert to Christianity to be educated (Snelson, 1974; Carmody, 2004). However, shortly after independence, the Catholic Church suffered a setback regarding control of education due to an inevitable nationalistic phase that enabled the newly-formed nation state of Zambia to take over control of most schools formerly administered by missionaries. Consequently, most mission schools were administered by the Zambian Ministry of Education (MoE), leaving only a few under missionary control such as the Catholic Church (Carmody, 2002:796). 
The third stage of educational provision in Zambia comprises the years after independence, that is, the period of a long educational partnership between successive Zambian governments and the Catholic Church.This period stretches from 1964 to date. During this stage, church missionary groups retained control of their schools from the government and the Catholic Church emphasised the maintenance of high educational standards in their schools. By the end of the colonial era in 1963, the Catholic Church was a leading provider of primary and secondary education in Zambia (Carmody, 2002:803). As a further indication of the undisputed involvement of the Catholic Church in Zambia's educational provision since the 1890s, the number of Catholic primary and secondary schools has increased tremendously in Zambia and the Catholic Church also administers grant-aided colleges of teacher education, community schools, skills training centres, orphanages and Cheshire Homes nationwide (Carmody, 1999; Carmody, 2007). Therefore, the Catholic Church played an important role in the provision of education in Zambia in the past and continues to do so today. Despite the current problem of undesired identity reformation, the education provided in Catholic schools still represents one of the best forms of Western formal education available to native people in Zambia, making the Catholic educational contribution to native education unprecedented.

The concept of identity is not easy to explain because it is not easy to give an outright statement of what the concept entails. The different explorations of the concept of identity given by various academics from various academic disciplines confirm how difficult it is to explain the concept.

From the field of psychology, Erik Erickson sheds light on what the concept of identity entails. In his adult development and personality theory, in which the concept of identity is perceived from a personal identity perspective, Erikson (1963) defines it as the distinctive characteristic belonging to any given individual or shared by all members of a particular social category or group. In his analysis of the concept, Erikson focuses more on the distinctive characteristics individuals and social categories or groups possess that make them unique. Such characteristics enhance their easy identification from other individuals or social categories or groups of the same kind.

Still from a psychological perspective, in stating what "identity" is, Atchley (1989:189) posits that "identity is a set of characteristics that differentiates self from others and that persists over time". In the same light, educational psychologists Zanden and Pace (1984:74) stress that identity' refers to "an individual's sense of placement within the world". This applies to an understanding that one attaches to oneself, a reflection of what is provided as answers to questions such as "who am I" and "who am I to be?"

From a sociological perspective, Kidd (2002) asserts that the concept of identity refers to how individuals think of themselves and their world, and that it deals with people's characteristics of thinking, reflecting and self-perception. As such, Kidd (2002) also provides three forms of identity, namely, individual identity, social identity and cultural identity. Individual identity involves the unique sense of personhood held by each person in their own right, social identity involves the collective sense of belonging to a group or an institution, identifying oneself as having something in common with other group members or members of a social institution, and cultural identity involves a sense of belonging to a distinct ethnic, cultural and subcultural group.

The concept of identity is a major philosophical concern, specifically in relation to the issue of personal identity and its determinants. This is because philosophers continue to ask questions concerning what being a person entails (Hanna, 2014; Locke, 1997). Personal identity theory is a philosophical confrontation with religiously oriented ultimate questions of our own existence such as "who are we?" and "is there a life after death?" (Nimbalkar, 2014:1). Philosophical analysis of the notion of identity is anchored in the provision of the necessary and sufficient conditions for the identity of a person over time, 
making it a diachronic problem of personal identity evidenced by the common, central philosophical argument that, in order to exist after death, there has to be a person after death who is the same person as the person who died (Nimbalkar, 2014:2). It is also anchored in the synchronic problem that is concerned with the characteristics of a given person at a particular time.

In the light of the various explorations of the concept of identity, it is clear that, in simple terms, the concept is anchored in characteristics or attributes that make people, social groups or, indeed, social institutions unique or distinct from one another. Such idiosyncratic characteristics form the true identity of people, social groups or institutions. Therefore, the identity of Catholic secondary schools entails those prototypical features or characteristics that make the schools distinct from other educational institutions.

International studies that investigate aspects of undesired identity reformation in Catholic education were reviewed for this study. The studies reviewed included an American study entitled "The education of Catholic Americans" by Greeley and Rossy (1996). The study, by means of interviews and survey methods, investigated the complex question of the extent to which Catholic education impacted on the religious beliefs and practices of adolescents and adults. As an aspect of undesired identity reformation in Catholic schooling, the study revealed that the fundamental mission of Catholic schooling, which is focused on strengthening and enhancing the Catholic faith among young people, was not being realised in any really significant way in Catholic schools in America (Greeley \& Rossy, 1996:113).

The studies reviewed also included an Australian study conducted by Marcellin Flynn. Flynn (1985) used data from questionnaires to answer the following important question, among others: Do Catholic schools have a religious and educational effect upon their students and, if so, is it in any way independent of factors in the students' home backgrounds? From the resultant data, Flynn (1985) concluded that parents play a key role in respect of the promotion of formal religious practices such as Mass attendance among their children. He further concluded that since there has been a major reduction in parental involvement in formal religious practices in Australia, the situation is worse among children who attend Catholic schools. As an aspect of undesired identity reformation in such schools, Flynn (1985:314) concluded that parents cannot place the duty to promote formal religious practice among the learners on the schools or expect schools to take over this responsibility when they do not practise the faith themselves.

Also reviewed in this study is a study entitled "Religion and Education in Zambia, 1890-2000 and Beyond" that Melvin Simuchimba conducted from within the Zambian context. Through vigorous documentary analysis, Simuchimba (2005) sought to trace the origin and development of Religious Education (RE) in Zambian schools from 1890 to date. As an aspect of undesired identity reformation in Zambia's education system and, particularly, in Zambian Catholic schools, Simuchimba (2005) highlights the changes that RE has undergone as a curriculum subject in Zambian schools. Specifically, he points out RE's evolution at "content level" over the years through the inclusion of the four major religious traditions from the Zambian context. The other evolutionary aspect he points out concerns RE's shift from a confessional subject to an educational subject, taking on educational aims in place of confessional aims over the years. From a Catholic perspective, the changes in RE as a curriculum subject in Catholic schools over the years are contrary to Catholic educational aims as directed in Catholic education policy, which is why they are categorised as aspects of undesired identity reformation regarding Catholic schooling in Zambia.

\section{Research Design}


A qualitative research approach was used for this study, because qualitative research is the most appropriate in instances where the phenomena being investigated are broad, without many previous theories or incomplete (Draper, 2004:642). Moreover, qualitative research was appropriate because the study's overall goal was extensive narrative understanding or development of theories. This is because, according to Hammersley \& Atkinson (1983:20), one of the major goals of qualitative research involves extensive narrative understanding of what is being studied as well as the development of theories. The qualitative data collection techniques employed in the study were semi-structured interviews, focus group interviews and document analysis. The use of these three data collection techniques allowed for an in-depth exploration of the problem of undesired identity reformation in Catholic secondary schools in Zambia's Southern Province. The use of different qualitative data collection techniques enhanced a broader view of the phenomena under investigation in the study (Creswell, 2009). A purposive sampling method was used, in that the researcher selected a specific universe of population to provide the solutions to the main research problem. Purposive sampling enhances the selection of information-rich cases, which promotes an in-depth study. Purposive sampling also involves selecting respondents from whom the researcher can learn a great deal in respect of issues of central importance to the purpose of the research (Patton, 1990:169). The sample used in the study consisted of 26 respondents in total and these respondents were 4 head teachers of Catholic secondary schools, 4 teachers of RE in Catholic secondary schools, 4 parents from Catholic secondary schools, the Secretary of Catholic Education, the Provincial Education Officer of Zambia's Southern Province and 12 grade 12 learners from Catholic secondary schools.

\section{Presentation Of Findings}

The aim of the study was to reflect critically on how a conflict of values in the evolving Catholic education policies and Zambian national education policies has affected the identity of Catholic secondary schools in Zambia's Southern Province.

Research findings in this regard revealed:

1. the presence of undesired identity reformation in Catholic secondary schools in Zambia's Southern Province;

2. that there has not been a conflict of values between Catholic education policies and Zambian national education policies that led to undesired identity change or reformation in Catholic secondary schools in Zambia's Southern Province since independence (1964);

3. that, in describing the undesired identity reformation experienced by Catholic secondary schools in Zambia's Southern Province, there is a need to point out its complexity or multidimensional nature. The undesired identity reformation experienced by such schools since Zambia's independence is multifaceted or is experienced at different levels, hence its complexity as alluded to earlier. It was further revealed that despite the multidimensional nature of this undesired identity reformation, it has led to two major undesired identity reformation outcomes, namely, a weakening "academic mission" and a weakening "religious mission" of Catholic secondary schools in Zambia's Southern Province; and

4. d) that Carmody's (2007) strong contentions on the causes of undesired identity reformation in Catholic schools do not apply in the case of Catholic secondary schools in Zambia's Southern Province. The four "genuine causes" of undesired identity reformation in Catholic secondary schools in Zambia's Southern Province are: 1. lack of adequate understanding of Catholic education policy by stakeholders of Catholic education, 2. contemporary challenges experienced by Catholic secondary schools, leading 
to the undesired weakening of either the academic or the religious mission of the schools, 3. the changed nature, role and place of RE in the curriculum of Catholic secondary schools and 4 . the outcome of more weakly classified and insulated Catholic schools after the 1965 Second Vatican Council reforms.

\section{Discussion Of Findings}

\subsection{The presence of undesired identity reformation}

In partial agreement with Carmody's (2007:550) contentions, the findings of the current study confirm the presence of undesired identity reformation in Catholic secondary schools in Zambia's Southern Province since independence. This problem is not merely imagined or invented; it is a part of reality in these schools. All research participants affirmed its presence in the schools and stressed its complex nature, seeing that it involves various aspects. However, despite its complex nature, it was evident from the views of the research participants that it weakened either the schools' religious or academic mission.

\subsection{No conflict of values between Catholic education policies and Zambian national education policies}

Contrary to Carmody's (2007:550) strong contentions regarding the causes of undesired identity reformation in Catholic schools in Zambia, the study revealed that there has not been a conflict of values between Catholic education policies and Zambian national education policies that lead to undesired identity reformation in Catholic secondary schools in Zambia's Southern Province. Views from research participants indicated that Carmody's (2007) contentions regarding the causes of undesired identity reformation could not apply to Catholic secondary schools in Zambia's Southern Province because of the following reasons:

\subsubsection{The Catholic Church's commitment to collaboration and cooperation}

Before the Second Vatican II Council of 1965, the Catholic Church mostly retreated from what it perceived as a hostile world in order to protect its established religious heritage. After the Vatican II Council, the Church embraced a spirit of collaboration and cooperation with various institutions such as governments, non-governmental organisations and others beyond its confines. This collaboration was meant to provide social services such as healthcare and education in various societies around the world, including Zambia. Research participants stressed that due to the Catholic Church's commitment to a spirit of collaboration and cooperation with the outside world following the Vatican II Council reforms, there has not been a conflict of values between the evolving Catholic education policies and Zambian national education policies since independence. Research participants stated that the Catholic Church always, at all levels, including at the level of education policy formulation and implementation, opts for collaboration and cooperation with all stakeholders rather than antagonism or conflict.

\subsubsection{Educational partnership grounded in dialogue, mutual agreement and cooperation}

There is no conflict of values between the two educational policies because the educational partnership between the Catholic Church and the Zambian government has, since its inception, always been characterised by a spirit of dialogue, mutual agreement and cooperation at all educational levels. These three key features of this educational partnership include the aspect of relations between the two educational policies. Research participants were convinced that the evolving Catholic education policies and Zambian national education policies are strongly grounded in an educational partnership characterised by these key features. From participants' views it was evident that in the 
Zambian education system, education policy decisions and choices are always made through dialogue, mutual agreement and cooperation among stakeholders such as the Catholic Church and the government.

\subsubsection{Ranked higher, but not a reason for undesired identity reformation}

In agreement with Carmody's (2007:550) contentions, the study revealed that Zambian national education policies are somewhat ranked higher than Catholic education policies in the Zambian education system. The government accords a higher regard to national education policies than Catholic education policies. However, there has never been a conflict of values in Catholic education policies and Zambian national education policies because the education partnership is grounded in a spirit of dialogue, mutual agreement and cooperation. As pointed out earlier, research participants emphasised that all education policy decisions and choices in Zambia's education system are made in a spirit of dialogue, mutual agreement and cooperation among all stakeholders and the Catholic Church and the government are not an exception in this respect.

\subsubsection{The general agreement of values in the two education policies}

An inspection of Catholic education policies and Zambian national education policies through vigorous document analysis revealed that there has not been a conflict of values since independence. Instead, a number of similar key educational values are contained in the policies in question. Vigorous document analysis of the two evolving education policies since independence indicated significant points of convergence rather than divergence of values. This implies a reduced or zero chance of conflict of educational values in the two policies. For instance, in both education policies the aim of education is to promote the holistic or balanced development of learners, involving all the important dimensions of a human being. Priority is not given to the poor and deprived in society in educational provision; emphasis is placed on universal access to educational provision at all levels and high priority is granted to quality educational provision to the people (MoE, 1977; MoE, 1992; MoE, 1996; Abbot, 1966; Vatican Congregation for Catholic Education, 1988). The similarity of key values in the two educational policies is an indication of an agreement of values between the policies rather than a conflict of values.

\subsection{The MoE's positive stance on Catholic education policy}

Participants' views also demonstrated that, in Zambia, the MoE has a positive stance on Catholic education policy because of two reasons. Firstly, Catholic education policy is based on Christian values, which are commonplace in Zambia. In 1991 Zambia was declared a Christian nation by Zambia's second republican president, Frederick Chiluba. Secondly, the Zambian MoE has a positive stance on Catholic education policy because, as indicated earlier, its values are similar to those upheld in the Zambian national education policies. Based on the above, it can be stated that the common educational values in the two education policies increased the compatibility between them, thereby avoiding any chance for a conflict of values contained in them.

\subsection{Description of undesired identity reformation}

The undesired identity reformation experienced by Catholic secondary schools in Zambia's Southern Province since independence is complex due to its multifaceted nature, which includes various aspects. Despite the multifaceted nature of this identity reformation, findings from the study revealed that over the years it has ultimately led to two major undesired identity reformation outcomes, namely, a weakening "academic mission" and a weakening "religious mission" of the schools in question. In terms of the weakening academic mission of Catholic secondary schools, it was evident from the views of the participants that the academic achievement levels of the schools had been falling over the years since independence due to increased indiscipline levels in the schools over the years and the problem of inadequate teaching and learning materials in the schools. In 
terms of the weakening religious mission of the schools, research participants indicated categorically that the Catholic religious culture and tradition in the school settings had been gradually diminishing over the years since independence in the Southern Province because of, among other things, the rise to prominence of an "academic culture" over a "religious culture" within the schools, most learners' negative attitude towards RE within school settings and the drastic reduction of members of Catholic religious orders (priests, brothers and nuns) at the schools.

\subsection{The four genuine causes of undesired identity reformation}

Carmody's (2007) contentions regarding the causes of undesired identity reformation in Catholic schools could not be applied in the case of Catholic secondary schools in Zambia's Southern Province. The study revealed four "genuine causes" of undesired identity reformation in the schools in question since Zambia's independence. These four causes are pivotal in explaining the nature and the scope of the undesired identity reformation experienced by Catholic secondary schools in Zambia's Southern Province since independence. The following is a description of the four genuine causal factors of undesired identity reformation in the schools.

\subsubsection{Stakeholders' inadequate understanding of Catholic education policy}

The study revealed that important stakeholders of Catholic secondary educational provision have an inadequate understanding of Catholic education policy in that they associate it only with Christian beliefs in education. This is a limited or restricted understanding, seeing that Catholic education policy incorporates various other significant aspects. Key stakeholders of Catholic education such as head teachers, teachers, parents and learners do not have a sound understanding of their own policy in Zambia's Southern Province. This is a major problem on the part of Catholic educational provision, because Catholic education policy stipulates that stakeholders of Catholic education at all educational levels are obliged to implement Catholic educational values in the schools in order to promote their Catholicity (Miller, 2006:12). The stakeholders' inadequate understanding of the very policy they are supposed to implement or promote in Catholic secondary school contexts makes it difficult or impossible to enhance the Catholicity of their schools. This outcome is one of the major causes for the undesired identity reformation experienced in Catholic secondary schools since independence.

\subsubsection{Catholic secondary schools and their contemporary challenges}

Challenges have been part of Catholic secondary educational provision in Zambia's Southern Province since the country gained independence. Findings from the study indicated that such challenges are partly responsible for the undesired identity reformation these schools have experienced since independence. Findings from the study further revealed that such challenges have specifically led to the undesired weakening of either the academic or the religious mission of the schools over the years. Anything that has a negative effect on the Catholic schools' academic and religious mission is an attack on the very nervous system of Catholic education because the two missions are a key part of what makes up Catholic education as prescribed in Catholic education policy.

\subsubsection{The changed nature, role and place of RE in the curriculum}

RE is a key subject in Catholic educational provision at all levels. This is owing to the extreme importance accorded to the balanced development of learners in the aesthetic, creative, critical, emotional, intellectual, spiritual, social, political and physical dimensions in Catholic educational provision at all levels (Hunt, Oldenski, \& Wallace, 2000:8). Holistic education is achieved through RE in a Catholic school (Hunt et al., 2000:8). Findings from the study revealed that RE has undergone undesired identity reformation at the levels of 
its nature, role and place in Catholic secondary schools over the years since independence. In terms of its nature, RE is no longer a fully Christian curriculum subject owing to the current inclusion of other major religious traditions from Zambia's context such as Islam, Hinduism and traditional Zambian beliefs. It terms of its role, it was evident from the findings of the study that RE's "confessional role" has been replaced by an "educational role" over the years as evidenced by the replacement of its confessional aims with educational ones. Regarding its place in the Catholic secondary school curriculum, findings from the study indicated that the subject has lost its pinnacle position to science-oriented subjects due to the negative attitude that some teachers and learners have towards the subject. Based on the above, findings from the study revealed that the changed nature, role and place of RE in the Catholic secondary school curriculum contributed a great deal to the weakening religious mission of the schools. The weakening of the schools' religious mission is one of the major reasons for the undesired identity reformation experienced in Catholic secondary schools in Zambia's Southern Province.

\subsubsection{Weakly classified and insulated Catholic schools after 1965}

Before the 1965 Second Vatican Council reforms, the Catholic Church was closed to the outside world for the sake of conserving its religious heritage. Consequently, Catholic schools were highly classified and insulated from the external world globally (Grace, 2002). As a result, the schools were highly distinctive and conservative in their character. After the 1965 Vatican II reforms, the Church redefined its external relations with the outer world at various levels. The educational outcome of this was the Catholic Church's commitment to openness to the external world in its educational provision at all levels and this partly meant allowing non-Catholic teachers and learners to access Catholic education at all levels worldwide. This transition by Catholic educational institutions following the 1965 Vatican II reforms signifies a global blow to their desired identity as recommended by Catholic education policy. This is because their adopted openness has made them more weakly classified and insulated from external agencies in the external world, making them extremely susceptible to undesired identity reformation (Abbot, 1966:12). Therefore, in terms of "identity", it is evident that certain external agencies or factors negatively affect such educational institutions. Findings from the study revealed, for example, that since Zambia's independence in 1964 to date, the welcoming of nonCatholic teachers and learners in Catholic secondary schools in Zambia's Southern Province has negatively affected the desired identity of such schools. This is because teachers and learners sometimes trivialise the Catholic culture and tradition within the school contexts, thereby weakening the religious mission of the schools. Therefore, the weakly classified and insulated nature of Catholic schools after 1965 is partly responsible for the undesired loss of identity experienced by Catholic secondary schools in Zambia's Southern Province.

\section{Conclusion}

In conclusion, it can be stated that, in line with Carmody's (2007:550) contention concerning the presence of undesired identity reformation in Zambian Catholic schools, it was evident in findings of the study that this aspect is, indeed, a reality in Catholic secondary schools in Zambia's Southern Province. However, the study disproves Carmody's other strong contention, namely, that a conflict of values in the evolving Catholic education policies and Zambian national education policies since independence is the cause for the undesired identity reformation experienced by Catholic schools in Zambia. The study revealed the non-existence of a conflict of values between the two education policies since independence. In providing a factual, definite and detailed account of the undesired identity reformation experienced by Catholic secondary schools in Zambia's Southern Province, four genuine causes of undesired identity reformation experienced by Catholic secondary schools were discussed. These genuine causes are: 1 . stakeholders' inadequate 
understanding of Catholic education policy, 2. contemporary challenges experienced by the schools, 3. the changed nature, role and place of RE in the curriculum and 4. weakly classified and insulated Catholic schools after the 1965 Second Vatican Council reforms.

\section{References}

Abbott, W. (ed.) 1966. Declaration of Christian Education. In The Documents of Vatican II. London: Chapman.

Atchley, R. 1989. A Continuity Theory of Normal Aging. The Gerontologist, 15(29):183-190.

Berman, E. 1975. African Reactions to Mission Education. New York: Teacher College Press.

Carmody, B. 1999. Education in Zambia: Catholic Perspectives. Ndola: Mission Press.

Carmody, B.P. 2002. The Politics of Education in Zambia 1891-1964. Journal of Church and State, 44(4):775-804.

Carmody, B.P. 2004. The Evolution of Education in Zambia. Lusaka: Book World Publishers.

Carmody, B.P. 2007. Catholic Church and State Relations in Zambian Education: A Contemporary Analysis. In International Handbook of Catholic Education Part II edited by Grace, G.R. and O’Keefe, J., 543-562. Dordrecht: Springer.

Creswell, J.W. 2009. Research Design: Qualitative, Quantitative and Mixed Methods Approaches: California: Sage Publications.

Chisempere, J. 1993. Dealing with Secularism and Materialism in a Catholic School. Jesuit Center for Theological Reflection Bulletin, 16(2):14 - 16.

Draper, A.K. 2004. The Principles and Application of Qualitative Research. Proceedings of the Nutrition Society Workshop on Developing Qualitative Research Method Skills: Analyzing and Applying your Results, London, May 19 and October 24, pp 641-646.

Erikson, E. 1963. Childhood and Society. New York: MacMillan.

Flynn, M. 1985. The Effectiveness of Catholic Schools. Homebush, NSW: St Paul Publications.

Garvey, B. 1994. Bemba land Church: Religious and Social Change in South Central Africa 1891 - 1964. Leiden: E.J. Brill.

Grace, G. 2002. Catholic Schools: Mission, Markets and Morality. London: Routledge Falmer.

Greeley, A. \& Rossi, A. 1996. The Education of Catholic Americans. Chicago: Aldine.

Hanna, K. 2014. The Philosophical Question of Identity. Available from: http://ezinearticles. com/?The-Philosophical-Question-of-Identity\&id=3494973 (Accessed 14 March 2014).

Hammersley, M. \& Atkinson, P. 1983. Ethnography, Principles in Practice. New York: Tavistock.

Hunt, T., Oldenski, T. \& Wallace, T. (eds.) (2000). Catholic School Leadership. London: Falmer Press.

Kabwe, F. 2010. Can Catholic Institutions Reclaim their identity? Jesuit Center for Theological Reflection Bulletin, 58(4):11 - 15.

Kelly, M.J. 1999. The Origins and Development of Education in Zambia. Lusaka. Image Publications. Kidd, W. 2002. Culture and Identity. Hampshire: Palgrave.

Locke, J. 1997. Essays on the Intellectual Powers of Man. London: Penguin.

Miller, J.M. 2006. The Holy See's Teaching on Catholic Schools. Atlanta: Sophia Institute Press.

Ministry of Education. 1977. Educational Reform: Proposals and Recommendations. Lusaka: Government Printers.

Ministry of Education. 1992. Focus on Learning: Strategies for the Development of School Education in Zambia. Lusaka: Government Printers.

Ministry of Education. 1996. Educating Our Future. Lusaka: Zambia Education Publishing House.

Nimbalkar, N. 2014. John Locke on Personal Identity. Available from: http://www.ncbi.nlm.nih.gov/ pmc/articles/PMC3115296/ (Accessed 14 March 2014). 
O'Brien, D. 2006. The Struggle for Control of Education in Zambia. Lampeter: Edwin Mullen Press.

Patton, M.Q. 1990. Qualitative Evaluation and Research Methods. Journal of Pennsylvania Law Review, 141(3):801-898.

Parker, F. 1966. Early Church-State Relations in African Education in Rhodesia and Zambia. London: Evans Bros.

Simuchimba, M. 2005. Religious Education in Zambia, 1890-2000 and Beyond. Unpublished PhD Dissertation. University of South Africa.

Snelson, P. D. 1974. Educational Development in Northern Rhodesia 1888 - 1945. Lusaka: Neczam.

Vatican Congregation for Catholic Education. 1988. The Religious Dimension of Education in a Catholic School. Dublin: Veritas.

Weller, J. \& Linden, J. 1984. Mainstream Christianity to 1980 in Malawi, Zambia and Zimbabwe. Gweru: Mambo Press.

Zanden, J.V. \& Pace, A. 1984. Education Psychology: In Theory and Practice. North Carolina: McGraw-Hill Publishing Co. 